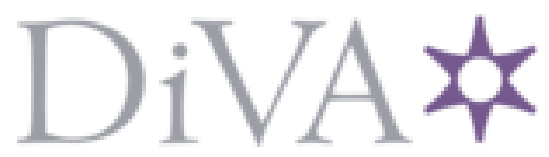

http://www.diva-portal.org

This is the published version of a paper published in British Journal of Aesthetics.

Citation for the original published paper (version of record):

Dammann, G. (2010)

Opera and the Limits of Philosophy: on Bernard Williams's Music Criticism.

British Journal of Aesthetics, 50(4): 469-479

http://dx.doi.org/10.1093/aesthj/ayq038

Access to the published version may require subscription.

N.B. When citing this work, cite the original published paper.

Permanent link to this version:

http://urn.kb.se/resolve?urn=urn:nbn:se:uu:diva-294017 


\title{
Opera and the Limits of Philosophy: on Bernard Williams's Music Criticism
}

\author{
Guy Dammann
}

This paper provides a reading of the opera criticism of Bernard Williams in the light of his philosophical writings. Beginning with the observations that his philosophical writing lacks engagement with musical and aesthetic issues, and his operatic writing appears to present no particular philosophy of the subject, I try to draw together certain themes by mapping Williams's operatic concerns onto his philosophical project more generally. I argue that the 'excessive' nature of the artform - the idea that opera tends to exceed its musico-dramatic functions - was of particular interest to Williams, partly because it resonated with his dislike of easy theoretical solutions to thorny practical issues. More specifically, Mozart's Cosi fan tutte is related, via the way the way its emotional register exceeds its dramatic context, to the issues examined by Williams in his work on moral luck. Similarly, I discuss the way Williams's essay on Debussy's Pelléas et Mélisande seems to hint at an account of the emotions which is otherwise missing from Williams's oeuvre.

Bernard Williams was working on two very different projects when he was diagnosed with the cancer that ended his life in 2003. ${ }^{1}$ He postponed the first, a collection of essays on the subject of opera, in favour of the second, which would turn out to be his last philosophical book. Published a year before his death, Truth and Truthfulness quickly established itself as one of the most intriguing recent defences of the notion of truth in the face of the perceived encroachment of relativism on scholarship and everyday thinking. Instead of offering a theory of truth, Williams put forward an argument for the necessity of truthfulness - of truth-telling and truth-intending - based on the idea that neither individual nor a community of language users can function without prizing truthfulness and its supporting virtues of accuracy and sincerity. His argument was highly unusual in espousing a commitment to truth in evaluative terms - roughly, that it is necessary to uphold truth because being truthful is so valuable to us - and in unfolding an account of truthfulness along genealogical lines similar to those he had used in his earlier and well-known elaboration of 'thick' evaluative concepts. $^{2}$

1 Bernard Williams, On Opera (New Haven, CT and London:Yale University Press, 2006) and Truth and Truthfulness (Princeton, NJ and Oxford: Princeton University Press, 2002).

2 Bernard Williams, Ethics and the Limits of Philosophy (London: Fontana Press, 1985), pp. 129ff. See also Hilary Putnam, '“Thick" Concepts and the Entanglement of Fact and Value', in The Collapse of the Fact/Value Dichotomy (Cambridge, MA and London: Harvard University Press, 2002), pp. 3443. 
It is not to be regretted that Williams gave priority to this book over his collection of opera essays, especially considering that the latter consisted of articles previously published elsewhere. After his death, the volume was edited by the philosopher's widow, Patricia Williams, and published at the end of 2006 as On Opera, with an introduction by his Cambridge colleague and opera-going companion, Michael Tanner.

There is nonetheless a sense in which one might have wished Williams had been allowed more time to work on the collection (in such as way as to make a whole greater the sum of the parts). Although it is clear in all the essays of which On Opera is comprised (and in particular in the opening essay, 'The Nature of Opera' ${ }^{3}$ ) that their author is not only an exceptionally learned and thoughtful student of opera but also a philosopher, the reader misses any sense of a philosophy of opera being advanced or developed. This is all the more of a shame when one considers that Williams himself apparently lamented that the amount of 'helpful operatic criticism' was so small. As Tanner puts it,

the questions, which it was [once] routinely assumed that critics should deal with, of the meaning and significance of a given work of art, and also of the art form to which it belongs, simply don't get dealt with in most of what passes for opera criticism. ${ }^{4}$

At the same time, there is a relatively little material specific to opera in the otherwise burgeoning literature on the philosophy of music. Given that Williams was both a thinker of unusual clarity as well as an opera lover of rare cultivation and critical self-awareness, the volume's failure to offer something approaching a through-composed philosophy of opera seems like a missed opportunity. ${ }^{5}$

This thought should not of course be taken as a negative assessment of the volume. Taken on its own terms - as a volume of musicologically and philosophically thought-provoking essays - On Opera surely makes for required reading for anyone who takes the genre seriously. A number of the essays, such as those on Don Giovanni, Cosi fan Tutte, Tosca, and Pelléas et Mélisande are classics of opera criticism. Others, such as the transcribed 1974 BBC radio lecture on 'Mozart's Figaro, A Question of Class?', or the previously unpublished lecture on Verdi's Don Carlos, might well have become classics too. And while some, such as the commentary on Paul Robinson's 1985 Opera and Ideas, ${ }^{6}$ or the address 'Authenticity

3 On Opera, pp. 1-19; originally published in Stanley Sadie (ed.), The New Grove Dictionary of Opera, 4 vols (London: Macmillan, 1992).

4 On Opera, pp. xv-xvi. Tanner, as both a philosopher and the opera critic of The Spectator, reasonably omits himself from 'a situation' which he suggests 'shows no signs of improving. On the one hand we have . . reviewers who merely do reports on the latest stagings and musical performances with no more general considerations in mind. . . On the other hand, we find academics writing essays or books which employ the latest literary critical jargon, or more often that of the latest "school" but one, and spin out their theories while vouchsafing no insights into the works they discuss, and so rightly have no impact on the interests of opera-goers' (ibid., p. xvi).

5 This is not to suggest that the critical essays contained in the volume are not motivated by or do not yield philosophical insights, or a concern for the 'meaning and significance' of operas as works of art. They certainly do, as will be discussed below.

6 Paul Robinson, Opera and Ideas: From Mozart to Strauss (Ithaca, NY: Cornell University Press, 1985). 
and Re-creation' to the International Musicological Society, show Williams as aware of and responsive to recent developments in academic writing about music and opera, most are refreshingly free of reference to intellectual trends or of jargon. They bear instead the mark of an astute mind and passionate listener paying his dues to and teasing out the deeper meaning from some of the operas he loves.

To be sure, Williams's opera criticism counted as a labour of love. This is quite evident in the last of the essays, dedicated to Isaiah Berlin, where Williams applies Schiller's distinction between the 'naïve' and the 'sentimental' to opera. ${ }^{7}$ Williams argued that just as there can no longer (after Verdi) be any naïve operas, so there can no longer be any naïve experience of opera. None the less, he observes, even if the entirety of operatic experience is shot through with reflectiveness, there remains one element left of the naïve. 'Opera is one case in which love is almost entirely expressed in enjoyment. What you love, you straightforwardly enjoy; you look forward to a performance, or at least one that promises to be tolerably good, with pleasure.'8

In Bayreuth, the year before his death, Williams made a remark deeply telling of his interest in opera to his student Lydia Goehr: 'I know a good deal about music, and a good deal about philosophy, but nothing about how they are connected-nor do I particularly want to.' Williams's love for opera might in this respect be characterized as 'naïve-sentimental' in the sense that he attended to it and wrote about it with the intellectual tools and cultural sophistication at his disposal, but wanted to maintain a distance between his musical passions and his philosophical work. If this is right, perhaps we should not look too closely for connections between his operatic writing and his philosophy. And yet, and this is what I aim to show in the remainder of this essay, the points of contact are potentially illuminating for both sides.

So what might have been Bernard Williams's philosophy of opera? This question is hard to answer, when asked of anyone. Like any self-reflective or written pursuit, the writing of philosophy is generally pointless to predict. It is hard enough to anticipate the direction of one's own writing let alone guess the path another might take. The problem is exacerbated by the fact that Williams generally spent little time writing about art and aesthetics in general and music in particular. ${ }^{9}$ Where references are made in his philosophical writings, they tend to be both fleeting and often by way of counter-example to the various catch-all, Archimedes-point strategies on which he so often waged his war of attrition.

7 Following Berlin's own precedent in 'The “Naïveté” of Verdi', Hudson Review, 21 (1968), pp. 138-147. Schiller's distinction is, roughly, between artists who are easily at one with their mode of expression, and artists whose unease with their mode of expression is part of their art.

8 On Opera, p. 133

9 The obvious exception is the chapter on 'The Makropulos Case: Reflections on the Tedium of Immortality', in Problems of the Self, pp. 82-100. Here, though, the object of discussion is neither Janá ek's opera itself, nor the kind of opera it is an example of, but rather the subject a consideration of the opera gives rise to, namely the idea that immortality is not so very desirable as all that. 
For example, in his critical discussion in Ethics and the Limits of Philosophy of Hare's prescriptivism, Williams reminds us that the evaluative sphere is not exhausted by the ethical, but also includes the aesthetic, a category which poses severe difficulties for prescriptivist models. One would be hard pushed, he suggests, to argue that aesthetic value, in typical cases at least, registers as a prescription for some action or other. This 'seems', as he puts it 'to require our basic perspective on the worth of pictures to be roughly that of potential collectors'. 10

In Truth and Truthfulness, when discussing various kinds of neo-Darwinism that aimed to explain the gamut of human action and intention in evolutionary terms, Williams cites the classical symphony as (for him) a self-evident counterexample to the idea that human culture can be explained in this way.

The generic human need to make and listen to music, for instance, might be explained at the level of evolutionary psychology, but the emergence of the classical symphony certainly cannot. In fact, the insistence on finding explanations of cultural difference in terms of biological evolution exactly misses the point of the great evolutionary innovation represented by Homo sapiens, the massive development of non-genetic learning. ${ }^{11}$

Williams was anxious at various points to assert that aesthetic value is something that should be taken seriously, just as artworks, qua manifestations of human value and intention, should be. Yet however robust when deployed as counter-examples, he never elaborated these commitments systematically.

If this is something of a lacuna in Williams's output, it is hardly an unusual one for philosophers of his generation and education. Oxford in the 1940s and 1950s was no hotbed of philosophical aesthetics. Moreover, as the present occasion of this journal's fiftieth anniversary suggests, analytic philosophical interest in aesthetics was hardly at its peak in Britain at this time - otherwise the journal would have been founded sooner. ${ }^{12}$

Nonetheless, Williams's general philosophical output does suggest a number of likely commitments which may be extended from his concept of value in general to his likely conception of aesthetic value in particular. The first of these, predictably, would be that there are no neat solutions. Williams was tireless in his scepticism about the application of theory to our ethical lives, and he would probably have said that our aesthetic experiences are also elusive of comprehensive theorizing.

This commitment would have been part and parcel of Williams's destabilization of 'absolute conception' theories. ${ }^{13}$ As the remark about the development of the symphony cited

10 Ethics and the Limits of Philosophy, p. 124.

11 Truth and Truthfulness, p. 28.

12 With certain exceptions, such as Collingwood, the subjects of aesthetics during the first half of the twentieth century was by and large the preserve of discipline-specific scholarship, such as art history and musicology. See Lydia Goehr, 'The Institutionalization of a Discipline: A Retrospective of the Journal of Aesthetics and Art Criticism and the American Society for Aesthetics, 1939-1992', JAAC 51 (1993), pp. 99-121.

The most famous of these is Williams's Descartes: The Project of Pure Enquiry (London: Penguin, 1978). 
above suggests, the distance between the perspective that explains the human appetite for musical experience in terms of evolutionary psychology, and the one that accounts for the value of certain kinds of musical experience in the context of life as it is lived, is immense. At the highest level of generality, one might infer a commitment to a broadly Kantian notion of aesthetic autonomy. But it is equally important to note Williams's evident divergence from Kant on the question of the universality of aesthetic judgements. Admittedly, this is among the most problematic, and obscurely presented, of Kant's prescriptions. ${ }^{14}$ Nonetheless, Williams's continued insistence that the virtues of truthfulness, accuracy, and sincerity apply to our ethical judgements, together with his evident observation of high standards of correctness in his opera criticism, may reasonably be extended to our judgements about aesthetic value. In this respect, he might have shared elements of Kant's view that aesthetic perception goes to the heart of what it is to be human. The difference between them, which is no small one, would then be that Kant's focus is on what is entailed by the 'sensus communis', and on what is held to be true for all mankind, at all times, whereas Williams's focus is on what one might describe as a 'sensus communalis', inevitably dependent on the historical and cultural milieu that shapes our values to such a large degree.

In a similar vein, contra Kant, Williams was clear about the legitimacy of maintaining a distinction between personal preference and evaluative judgement which cannot be folded neatly into Kant's distinction between the beautiful and the agreeable.

For many kinds of thing, you may distinguish between thinking that a given item is good of its kind and liking, wanting, or choosing that item; moreover, your ability to make that distinction shows that you understand that the merits of the thing in question may go beyond your own interests or power of response. Philosophy cannot make logically compulsory the attitude of a man I knew who, in one of those discussions of what bad music you most enjoy, said 'I find I can survive on a diet of masterpieces.' ${ }^{15}$

Although there may have been an aspect of wishful thinking in the anecdote with which this passage concludes, one is slightly left hanging by the way the distinction is drawn. Again, the observation is offered as a counterexample, a rhetorical device that deflects the demand for elaboration. However, we know from his work, say, on moral luck, that Williams thought that the distinction between judgement and preference was highly complex. As Williams himself argued convincingly, both reason and uniformity of opinion may unite in affirming our innocence or guilt in some ethical matter, but this can remain at odds with the way we 'feel' about the matter. Even if our peer group absolves us of responsibility for some tragic event, and we are convinced that their judgement is correct, we may yet continue to feel a sense of guilt and responsibility that cannot simply be discounted on the grounds that it is unreasonable. ${ }^{16}$

14 Immanuel Kant, Critique of Judgement, trans. W. S. Pluhar (Indianapolis: Hackett, 1987), §32, p. 281.

15 Ethics and the Limits of Philosophy, pp. 125-126.

16 See Williams, 'Moral Luck', in Moral Luck: Philosophical Papers, 1973-80 (Cambridge: Cambridge University Press, 1981) 
If this was taken by Williams to show that ethics cannot be reduced to purely rational categories (hence the idea of 'luck' applying in a moral context), it also suggests there is something important about the tension between a judgement and an emotional response which colours the experience of the latter, and often intensifies it, when the two are in opposition. Clearly, the aesthetic equivalent of a moral conflict between our 'agent-centred' feelings about some matter and our communicable judgement about it is less problematic. The fact that we may accept the general estimation of Beethoven's genius and combine this with a dislike of his music is easier to accommodate than that we accept the general view that, say, murder is wrong while taking an unusual delight in committing it. Nonetheless, the fact remains that the emotional responses through which our aesthetic preferences are manifest (as distinct from, say, a more apparently emotionally neutral estimation of something's worth) must necessarily play a significant role in the way we both make our own judgements and agree, or disagree, with those of others.

The best example of this kind of conflict in Williams's own experience is with the operas of Puccini. At the time Williams's own musical tastes were being formed, it was not unusual to 'mistrust' Puccini on the grounds, adapting Mark Twain's famous remark about Wagner, that his music is not as good as it sounds. But Williams, conscious of what might be taken as a simple prejudice, elaborated his position in one of the most astute and philosophically loaded essays to have been reproduced in the collection. After noting several flaws in Tosca - " "Vissi d'arte" is not a very interesting piece ... "E lucevan le steele" leaves a desultory impression and seems not to contribute enough to the significance of the action'-Williams comments that this seems in no way to compromise the work's success as an opera. ${ }^{17}$ As it soon becomes clear, this remark is not merely pointing to an instance of the all-too-familiar conflict between popular success and critical suspicion. Rather, it is that for critical and uncritical audiences alike, Tosca remains superbly compelling in spite of its being dramatically and musically compromised.

It is hard to think of a parallel to this in non-musical drama. . . . [T] he critical resistance to Puccini lies principally in the conviction that there is something manipulative or even cynical about his work. That conviction is, in my view, basically right. But that leaves the problem, since these manipulative works resemble, in their capacity to hold us, operas which have no such faults. If opera is at all a serious business, how can this be? This is the question about Puccini, and its answer lies in what it is like to experience opera. $^{18}$

In addition to presenting an exceptionally astute analysis of Puccini, Williams also hits firmly on its head a nail that penetrates deeply into the problematic nature of opera itself. This problem does not consist, as is often held, in opera's being 'awkward' in its combination of spoken drama with music, and thus its need to represent speech through song. ${ }^{19}$

17 'Manifest Artifice' in On Opera, pp. 99-106, p. 100

18 Ibid., p. 101-102.

19 This artifice, as Williams reminds us, is no more remarkable than any other artificial technique at work in dramatic representation, such as the use of blank verse (ibid., p. 102). 
Rather it consists in the fact that the manner of representation is itself what is partly - and at times principally - the object of our awareness. Our aesthetic pleasure, in other words, is not bound up entirely with the represented drama, or tied to the emotions possessing the characters on the stage, but also occurs as a conscious enjoyment of the techniques used to engineer the representation. It is as if the 'twofoldness' which Wollheim suggested is characteristic of the way we look at pictures were itself part of what is being pointed to in opera: we enjoy, in the phrase Williams takes for his title in the Puccini essay, its 'manifest artifice. ${ }^{20}$

Opera is, in this very pertinent sense, excessive. The experience is not exhausted by the perceived fulfilment of a dramatic or expressive brief, but also involves a kind of aesthetic surplus which in some way appears to demand admiration and enjoyment as additional. The pleasure of being absorbed in the emotions of the drama and music is not enough: one must also delight, as it were, at the manner in which this absorption is exacted. What Williams observes in the essay on Puccini is the way this operatic surplus may be seen to come adrift, to the potential detriment of the drama but without, curiously, our aesthetic enjoyment of the opera being greatly affected in the process.

What is clear, however, is that Williams retains the view that this is nonetheless still to be considered a fault, a deviation from an operatic ideal of the perfect integration of musical and dramatic form. In this respect, Williams's view of both opera in general and Puccini in particular is very much of a piece with that of the American musicologist Joseph Kerman, whose 1956 text Opera as Drama still occupies a central position in the musicological literature on opera. ${ }^{21}$ According to Tanner, ${ }^{22}$ Williams reserved some suspicions about Kerman, not so much about his conception of opera in general, or his interpretations of individual operas, but rather concerning his status as a kind of self-appointed F. R. Leavis of music, responsible for drawing up a central canon of exemplary works distinguished by a certain moral seriousness and a high degree of functional integration between musical argument and drama. ${ }^{23}$ I suppose that these suspicions were rooted in something like the realization, outlined above, that a significant part of opera's value lies in fact in its tendency to exceed itself as drama, because otherwise Williams sticks fairly closely to both the contours and conception of Kerman's canon, with Mozart's Da Ponte operas very much at their centre. ${ }^{24}$

20 See Richard Wollheim, 'Seeing-in, Seeing-as, and Pictorial Representation', in Art and its Objects, 2nd edn (CUP, 1980), pp. 205-226.

21 Joseph Kerman, Opera as Drama (Berkeley and London: University of California Press, 1955).

22 Introduction to On Opera, p. xvii.

23 Verdi's Don Carlos was Williams's favourite opera.

24 For example, as recently as 2002, in an essay on Janáček written for Alexander Goehr's seventieth birthday Festschrift, Williams's enthusiasm for the composer was tempered by the perceived inadequacy of his immediate music to the dramatic requirements of his material: 'There is no need to suppose that Janáček's operas are among the very greatest. . . In particular, the sacrifice of musical development carries a substantial cost.' The latter remark, in particular, would also risk cutting adrift a sizeable body of now thoroughly rehabilitated baroque opera, as well as much twentieth-century opera. 
It is interesting, then, that the point on which Williams finds his strongest interpretative disagreement with Kerman concerns one of the Da Ponte operas. Cosi fan tutte has long since shed the negative associations that dogged its history from composition. These mostly had to do with its supposedly immoral character but also extended, according to Wagner among others, to its musical qualities. ${ }^{25}$ But by the time Kerman characterized it as 'Mozart's most problematic opera' - a moniker that would now more likely be given to Don Giovanni-Cosi was on the cusp of gaining the central position in the repertoire it held for much of the second half of the last century. ${ }^{26}$

The problem, as Kerman understood it, lies principally with the second act, in which Guglielmo and Ferrando, disguised as 'Albanians', renew in earnest their attempts to seduce each other's beloveds. Though a common enough device in comedies of errors of this kind, Kerman found that the music through which the agonies of Fiordiligi, in particular, are expressed is so powerful that it quite exceeds the comic context provided by the libretto. ${ }^{27}$ Williams expresses the issue in a manner strongly reminiscent of the Puccini case:

The complaint is not merely that the work is in some formal or purely architectural terms awry, a technical failure; it is rather that the strain which develops between the text and music generates something which is not just imperfect but unacceptable. ${ }^{28}$

As it turns out, however, the case of Cosi is not the same as Tosca, in which, as we have seen, Williams locates a kind of manipulative dishonesty. Rather, Williams finds the tension between the musical and dramatic structure in the Mozart opera to be one of its most interesting and stimulating qualities. 'It is not a perfect work . . . but it is a deep and unsettling masterpiece which, like some other eighteenth-century works, plays disquietingly across the formalities of its structure. ${ }^{29}$

What are we to make of the apparent contradiction in which Williams condemns (with reservations) one opera in the terms used to praise another? On the face of it, the distinction seems to be a moral one: while Williams sees the operatic excess of Tosca as, ultimately, feeding into a self-indulgent manifestation of the composer's fascination with cruelty and sadism, in Cosi he sees it as drawing attention to something of significantly greater moral and philosophical value. For according to Williams it is not the case that Mozart ascribes, as it were for 'operatic' reasons, to the character of Fiordiligi emotions that cannot be squared with the demands of the comic plot. Rather, Fiordiligi's pain is real and justified enough within the context of the opera (if not necessarily the libretto), but runs into conflict with the opera's simultaneous demand that, as a comedy, such extremes of emotion

25 See Richard Wagner, Opera and Drama in Wagner on Music and Drama, trans. H. Ashton Ellis (London: Gollancz, 1970), p. 100.

26 Opera as Drama, pp. 109ff.

27 Kerman considered Da Ponte's libretto to be 'frivolous [and] unworthy of Mozart'. Cited in On Opera, p. 44.

28 Ibid., p. 45.

29 Ibid. 
must be passed over, life must move on and the action proceed swiftly to its happily-everafter ending. Understood in this manner, Cosi represents not so much a conflict between opera and drama as an example of opera significantly expanding the range of a drama, and at the same time making a valuable comment both on the subject of comedy in general (that it often plugs the gaps left by tragedies), and on the containment of emotion in particular. Così, as Williams puts it, says to us:

Look . . . this is very often how it is, that real forces of emotion and desire are met and acknowledge and carry the most serious conviction, yet the world rattles on as though it were not so; the conventional order makes its bleakly reasonable demands. ${ }^{30}$

Perhaps, then, the structural conflict in Così held so much interest and appeal for Williams because it precisely concerns, in a manner similar to the case of moral luck, a lack of equilibrium between an emotion and the context in which that emotion may find itself expressed. Cosi thus may arguably be seen almost as symbolic of a significant aspect of Williams's philosophical endeavour-namely the effort to explain that the attempt by philosophers (from Descartes to Hare) to factor out the emotional-evaluative aspects of our cognitive lives in the interest of metaphysical or epistemological neatness has seriously messy implications. It also suggests, in the way that opera forces a confrontation with emotion that both real life and philosophy, in Williams's view, often contrive to avoid, that Williams's thirst for and enjoyment of opera were both strongly tied to his wider philosophical project.

If Così is in this sense emblematic of an important element in Williams's philosophical enterprise, then his love of Debussy's only opera, Pelléas et Mélisande, might be understood conversely, as an emblem of something absent from this enterprise. For although emotion played a consistently central role in Williams's thought, he never developed anything like a systematic theory of the emotions. In this respect, his remarks on Pelléas give a tantalizing impression of what such a theory might have looked like, and of how it might have related to art in general, and to opera in particular. Williams picks up on a remark of Debussy's about Wagner's use of leitmotiv.

I hate the leitmotiv . . not only when it is abused, but even when it is used with taste and discernment. Do you think that in composition the same emotion can be expressed twice? In that case, either one has not reflected, or it is simply an effect of laziness. ${ }^{31}$

The key here for Williams is the point about emotion not being expressed twice, which suggests to him that Pelléas can very well be viewed in a way that differs strikingly from the interpretative orthodoxy which supposes it 'is all about inescapable fate and that the characters are all passive victims'.

$30 \quad$ Ibid., pp. 45-46.

31 Claude Debussy in conversation with Maurice Emmanuel. The remarks were made some twenty-five years before the composition of Pelléas. See Léon Vallas, Claude Debussy: His Life and Works, trans. M. and G. O'Brien (OUP, 1944), pp. 83ff. Cited in On Opera, p. 90. 
The theme of overwhelming fate, or an inert belief in the hopelessness of all action, is not the point. . . There is emphasis in the story of Pelléas on the imperfection of action; but it is to trivialise this, and to lose its tragic quality, if one reduces it to a blank, external and preordained fate. ... [O]ne of Arkel's sage observations . . . comes nearer to the heart of this work: when he says, and it is practically the very first thing he says, that we see only the back of destiny, even of our own. . . . So we do see something, but what we see is the wrong way round, and also fragmentary, gaining a sense only from a different point of view. So we can only imperfectly understand what we or others do. ... What the opera tells us is that to many of the questions that we are driven by our fears to ask about ourselves and others, there are no answers; and that it is essential to the life of the feelings to recognise that fact. ${ }^{32}$

Beyond the world of the opera itself, Williams's target here is clearly the thorny issue of the way we come to understand things whose proper manifestation is and only is as experienced through time. Numbered among these things, obviously, is the category of the emotions and it is in virtue of Debussy's refusal to treat emotions as states of mind susceptible of being captured or frozen that prompts Williams to consider Pelléas, rather counterintuitively, as a realistic opera. The idea that the same emotion may not be expressed twice arises, therefore, in this context not as a trivial stylistic objection to what he later called Wagner's habit of leaving musical 'calling cards', ${ }^{33}$ but rather as an astute observation about the way emotions constantly flee the scene of their prospective cognition. To grasp an emotion is, then, in an important sense no longer to be grasped by it, and to suggest that one feels the same thing twice, any more than to suggest that a theme or note is heard the same way when it is repeated, is to make an error about the nature of feeling. Certainly it is something along these lines, or so it seems to me, that Williams is pushing towards here and it is notable that he chose a musical context in which to express it.

It is interesting, in this connection, that a similar point arises at the end of his discussion of Janáček. Despite Williams's reservations about the composer, which do not in fact seem to amount to very much, he reserves rich praise for the way in which he employs - in a manner certainly comparable to that of Debussy - 'a very original modernist technique to cut through its own peculiarities and to produce something that is experienced as an exceptionally direct address to very powerful feelings'.

A philosopher will understand, ruefully enough, that no philosophical words can ever do what music can do, in this as in many other respects. Yet Janáček can stand as a reminder even to a philosopher of what should be done: granted essential technical

32 Ibid., pp 92-93.

33 In an interview with Robert de Flers in Le Figaro, 1902. He continues: 'I must confess that I find this procedure somewhat gross. Also, the symphonic development that he introduced into opera appears to me to conflict continually with the moral argument in which the characters are involved and with the play of passions, which alone is important.' Cited in Debussy on Music: The Critical Writings of the Great French Composer, ed. and trans. F. Lesure and R. Langham-Smith (Ithaca, NY: Cornell University Press, 1988), p. 80. 
complexity and inescapable self-consciousness, to address, express and restructure real emotions in ways that neither evade them with formalism nor degrade them into kitsch. $^{34}$

Philosophy's limits were always, of course, a familiar theme in Williams's thinking, but perhaps it was in opera that he was at his most comfortable living with them. One should not be tempted to speak of a resignation of the philosophical task here. For it is clear in all the essays in the volume that the thoughts and problems that exercised Williams in his philosophical life were the same thoughts and problems that drew him to the opera house and to engage with the works performed there both seriously and lovingly. Perhaps his keenness, as witnessed to Goehr in Bayreuth, to keep his philosophy separate from his opera was less a statement of fact than an indication of a desire to reserve space for his own passion for the genre. For as Williams demonstrates, it is precisely by acknowledging one's passion for opera - for its spectacle, its dramatic absurdities and aesthetic excess - that one can accommodate its philosophical potential. With this in mind, we may miss in Williams's opera writing the development of a full-bodied philosophy of opera. What we cannot miss, however, is his considerable raising of the stakes concerning the imperative to speak truthfully about the artworks one loves.

Guy Dammann

Guildhall School of Music and Drama

guy.dammann@gsmd.ac.uk 